\title{
Biomass production of the aquatic macrophyte Ceratopteris pteridoides (Hook.) Hieron (Pteridaceae) in nutrient addition treatments
}

\section{Aurélia Bentes Ferreira ${ }^{1,2}$ (D), Luiz Rubens Piedade ${ }^{1}$ (D) Maria Teresa Fernandez Piedade ${ }^{1}$ and Aline Lopes and $^{1,3 *}$}

Received: May 14, 2020

Accepted: August 18, 2020

\begin{abstract}
Aquatic macrophytes are a key group in flooded areas due to their high primary productivity, and several species present in the Amazonian floodplains have potential for human food use. This study evaluated biomass production and nutrient levels in fronds of Ceratopteris pteridoides (Pteridaceae), under the following nutritional treatments: (T1) artesian well water, (T2) natural lake water, and (T3) artesian well water with a nutritive solution. Each replicate had 25 plants of $25 \mathrm{~g}$ total fresh biomass each. The experiment lasted for 35 days and total fresh biomass weight, root system length, leaf dry biomass weight, root dry biomass weight and sprout number were assessed. The plants from T3 had the greatest increase in total fresh biomass with an average of $430.02 \mathrm{~g}$, showing that the nutritive solution used in the experiment provided the best conditions for plant growth. The daily ingestion of C. pteridoides could contribute to mineral supplementation, in addition to diversifying existing crops and contributing to sustainable agriculture.
\end{abstract}

Keywords: amazonian floodplain, mineral nutrition, potential food, unconventional food plants (UFPs), wild vegetables.

\section{Introduction}

Studies show that for over 10,000 years the domestication, cultivation, and management of plant species have been practiced by farmers, indigenous peoples and traditional communities around the world and this knowledge of the free use of biodiversity is one of the main bases of agriculture (Packer 2012). However, the modern, globalized food system has led to a simplified diet and increased dependence on some basic crops for most nutritional needs (Johns \& Eyzaguirre 2006). A survey of the world's vegetables indicates that only 402 species are grown worldwide (Kays \& Dias 1995). Young leaves or buds are the most consumed ( $53 \%$ of the total) and, as most are perishable, sale should occur soon after harvest, usually in local markets (Dias 2012).

As a general trend, the daily consumption of vegetables in the diet is closely associated with good health and the reduction of the risk of various diseases, as vegetables are important sources of vitamins, minerals, dietary fibers and phytochemicals for humans. Consumers are increasingly becoming more interested in healthy vegetable products due to their functionalities and food benefits (Dias 2015). Nutrition is a matter of quantity (biomass production) and quality (nutritional content), and vegetables ensure adequate intake of most compounds (Kays \& Dias 1995). Although they still require studies related to propagation and consumption, several wild vegetables are gaining more interest, especially in regions with a rich diversity of plant

1 Instituto Nacional de Pesquisas da Amazônia, Ecologia, Monitoramento e Uso Sustentável de Áreas Úmidas, 69067-375, Manaus, AM, Brazil

2 Pós-graduação de Botânica, Instituto Nacional de Pesquisas da Amazônia, 69067-375, Manaus, AM, Brazil

3 Instituto de Ciências Biológicas, Universidade de Brasília, 70910-900, Brasília, BR, Brazil

* Corresponding autor: alopesmga@gmail.com 
species such as the Amazon (Brasil 2010; Kinupp \& Lorenzi 2014).

The Neotropical region has the highest diversity of macrophyte species on the planet, with about 1,566 species (Chambers et al. 2007). There are a variety of fruits and seeds of aquatic plants that could be used as food for human, since many are rich in oils, starch, or proteins. Numerous rhizomes and tubers are rich in carbohydrates, especially starch, sugar, and mucilage. The foliage of many may also be used as salad ingredients. The rhizome of many aquatic macrophytes is also used as flour to produce cookies and cakes, among others. In Brazil, one of the most used macrophytes with nutritional value for humans is watercress (Nasturtium sp.) (Thomaz et al. 2009).

Aquatic macrophytes are a key group in freshwater ecosystems due to their high primary productivity, and several species growing in wetlands are potential sources of food. One example is Victoria amazonica, whose seeds and rhizomes are used in the diet of the riverine populations of the Brazilian Amazon (Piedade et al. 1991; 2010). Some frequent species, such as Neptunia oleraceae, Ipomoea aquatica and the pteridophytic Ceratopteris pteridoides, are among the species commonly commercialized and consumed in Asia as vegetables; however, in the Brazilian Amazon, they are used only to feed domestic animals (Piedade \& Junk 2000). The population in the Amazon region does not consume some of the native plants often because of their inability to identify the species, lack of information regarding their forms of use or their edible parts, and also due the loss of traditional knowledge (Kinupp \& Lorenzi 2014). However, some aquatic native species have potential for human consumption (Kinupp \& Barros 2008), provided that their biomass production, nutritional value and yield is known.

Ensuring access to nutritious food for the world's population is one of the main challenges of the $21^{\text {st }}$ century (ONU 2015). In order to produce sufficient, high-quality biomass that can be converted into leafy vegetables, it is necessary to identify the production strategies for traditional species (Mafeo \& Mashela 2009). The demand for a greater variety of plant species can be satisfied by assessing the suitability of less well-known edible species, including C. pteridoides.

In Brazil, C. pteridoides grows in the Atlantic Forest, the Pantanal, the Cerrado and the Amazon biomes (Hirai \& Prado 2020), especially in the nutrient-rich floodplain ecosystem found along the Amazon River (Piedade \& Junk 2000). The fronds of the species are consumed in oriental countries in salads, often together with fruit, and mainly in rural areas are also frequently eaten cooked (Liu et al. 2012; Panda 2015). There is currently no information on the cultivation of macrophytes, i.e., C. pteridoides, for human consumption, especially in hydroponic systems. Hydroponics is an efficient technique that allows the modulation of the nutrient solution based on the exclusive needs of each cultivated species (Furlani et al. 2009). It also provides greater yield with fewer fertilizer inputs and without compromising the quality and safety of the vegetables (Rodrigues 2002). Therefore, it is of extreme importance to develop methodologies for adapting promising species from the Amazon for large-scale production using hydroponics. Through greenhouse experiments, this study analyzed the growth and the incorporation of biomass of $C$. pteridoides that were collected in the natural environment and cultivated in water with different mineral contents in order to evaluate the species potential for human consumption.

\section{Materials and methods}

Ceratopteris pteridoides (Hook.) Hieron. is a fern of the Pteridaceae family. It is an aquatic plant that is free-floating or rooted in mud and occurs in environments with a high nutritional level such as the Amazonian floodplain lakes (Guterres et al. 2008; Piedade et al. 2019). This species has dimorphic fronds composed of a petiole with 4-many vascular bundles and sterile lamina that are simple or deeplylobed to pinnatifid or 1-3-pinnate, glabrous, succulent to herbaceous (Hirai \& Prado 2020). It also has vegetative reproduction through the formation of sprouts (Piedade et al. 2019).

Specimens of $C$. pteridoides with only vegetative fronds were collected in December 2014, in the Catalão Lake ( $3^{\circ} 10^{\prime} 04^{\prime \prime}$ S; $59^{\circ} 54^{\prime} 45^{\prime \prime} \mathrm{W}$ ), which is located in the Central Amazon. The lake is periodically influenced by the acidic and nutrient poor waters of Negro River and by the Solimões River, which is rich in nutrients and sediments (Brito et al. 2014). White-water rivers, like the Solimões, present fertile waters, with a $\mathrm{pH}$ close to neutral and high electrical conductivity due to the high concentration of dissolved ions (Sioli 1968). Despite receiving the waters of the Negro River, throughout the year, the physical and chemical properties of the Solimões River predominate in the Catalão Lake, which is why it is classified as a fertile floodplain lake (Brito et al. 2014).

The plants collected for the experiment were allocated in pots containing water from the same collection site and brought to the Instituto Nacional de Pesquisas da Amazônia (INPA), where they were washed in a sieve with running water and then placed on absorbent paper for 5 minutes to remove excess water. Every individual plant was weighed using a precision scale $0.1000 \mathrm{~g}$ (Gehaka, AG 200, Brazil). The initial fresh weight of the plants varied from 0.60 to $1.30 \mathrm{~g}$. The individuals were taken to the greenhouse of the MAUA Group - INPA/MAUA Project, where the experiment was conducted. The experimental design consisted of 3 treatments with five repetitions. Each repetition was composed of 5 plants with a total of 5 grams of fresh weight in each pot. The experiment comprised a total of 25 plants and 25 grams per treatment, as follows: $\mathrm{T} 1$ - water from 
the artesian well at INPA ( $37 \mu \mathrm{mol} \cdot \mathrm{L}^{-1} \mathrm{Na}^{+}, 24 \mu \mathrm{mol} \cdot \mathrm{L}^{-1} \mathrm{Cl}$, $8 \mu \mathrm{mol} . \mathrm{L}^{-1} \mathrm{~K}^{+8}, 8 \mu \mathrm{mol} . \mathrm{L}^{-1} \mathrm{Ca}^{2+}, 3 \mu \mathrm{mol} . \mathrm{L}^{-1} \mathrm{Mg}^{2+}$; Souza-Bastos et al. 2017); T2 - water from the Catalão Lake (208.0936 $\mu \mathrm{mol} . \mathrm{L}^{-1} \mathrm{Na}^{+}, 131.1856 \mu \mathrm{mol} . \mathrm{L}^{-1} \mathrm{Cl}, 87.6928 \mu \mathrm{mol} . \mathrm{L}^{-1} \mathrm{~K}^{+8}$, 964.7092 $\mu \mathrm{mol} . \mathrm{L}^{-1} \mathrm{Ca}^{2+}, 118.8096 \mu \mathrm{mol} . \mathrm{L}^{-1} \mathrm{Mg}^{2+}$; Souto et al. 2015); T3 - water from the artesian well of INPA + nutritive solution (See the composition below). The plants were distributed in a completely randomized design with five replicates per treatment. The same procedure was carried out for the distribution of the experimental units on the benches of the greenhouse.

For the climate of the northern region of Brazil, nutritional solution should be diluted until reaching an electrical conductivity in the range of 1.0 to $1.5 \mu \mathrm{S} . \mathrm{cm}^{-1}$ (Abou-Hadid et al. 1995). This is because the high temperature increases the physiological activity, and plants absorb more water than nutrients, thus, the ideal $\mathrm{pH}$ for cultivation is between 5.5 and 6.5 (Furlani et al. 2009). The commercial nutrient solution kit for hydroponics Hortibras ${ }^{\circ}$ (\$ 4.00 for $1,000 \mathrm{~L}$ ) was used to simulate hydroponic conditions that could easily be performed at low cost by farmers. To establish the proper dosage for the growth of the species, 40 concentrations ranging from $0.5 \mathrm{~mL} . \mathrm{L}^{-1}$ up to $10 \mathrm{~mL} . \mathrm{L}^{-1}$ of water were previously tested, according to the manufacturer's recommendations, and the dosage $0.5 \mathrm{~mL} . \mathrm{L}^{-1}$ resulted in plants that appeared visibly healthy. The T3 treatments followed the chemical adjustment method of the nutrient solution proposed by Furlani et al. (2009), which is based on the adjustment of electrical conductivity and $\mathrm{pH}$, containing $1,200 \mathrm{~g} \mathrm{KNO}_{3} 10 \mathrm{~L}^{-1} ; 200 \mathrm{~g} \mathrm{NH}_{4} \mathrm{H}_{2} \mathrm{PO}_{4} 10 \mathrm{~L}^{-1}$; $240 \mathrm{~g} \mathrm{MgSO}_{4} \cdot 7 \mathrm{H}_{2} \mathrm{O} 10 \mathrm{~L}^{-1} ; 600 \mathrm{~g} \mathrm{Ca}\left(\mathrm{NO}_{3}\right)_{2} \cdot 4 \mathrm{H}_{2} \mathrm{O} 10 \mathrm{~L}^{-1} ; 300 \mathrm{~g}$ $\mathrm{NH}_{4} \mathrm{NO}_{3} 10 \mathrm{~L}^{-1} ; 10 \mathrm{~g} \mathrm{MnSO}_{4} \cdot 4 \mathrm{H}_{2} \mathrm{O} \mathrm{L}^{-1} ; 5 \mathrm{~g} \mathrm{H}_{3} \mathrm{BO}_{3} \mathrm{~L}^{-1} ; 2 \mathrm{~g}$ $\mathrm{ZnSO}_{4} .5 \mathrm{H}_{2} \mathrm{OL}^{-1} ; 1 \mathrm{~g} \mathrm{CuSO}_{4} .5 \mathrm{H}_{2} \mathrm{O} \mathrm{L}^{-1} ; 1 \mathrm{~g} \mathrm{Na}_{2} \mathrm{MoO}_{4} \cdot 2 \mathrm{H}_{2} \mathrm{OL}^{-1}$ and $200 \mathrm{~mL}$ of Fe-EDTA. The $\mathrm{pH}$ of the solution was kept in the range of 5.5 to 6.5 in both $\mathrm{T} 1$ and T3. The electrical conductivity recorded was $1.3 \mu \mathrm{S} . \mathrm{cm}^{-1}$ and $1.2 \mu \mathrm{S} . \mathrm{cm}^{-1}$, which is within the appropriate recommended range.

The plants were allocated in 15 polyethylene containers, with $39 \mathrm{~cm}$ in diameter at the base, $50 \mathrm{~cm}$ at the opening and $30 \mathrm{~cm}$ high with a capacity of 40 liters each and allocated in a bench with dimensions of $3 \mathrm{~m} \times 2 \mathrm{~m}$ and $1.5 \mathrm{~m}$ high. The greenhouse was covered with black screens providing $25 \%$ shade. In all treatments, the water was changed weekly, and the $\mathrm{pH}$ and conductivity were monitored daily.

The fresh weight, root length and the number of sprouts were assessed every 10 days and the plants were returned to the experiment. At 35 days, the fronds of T3 start to produce fertile leaves, and were therefore considered to be in the harvesting phase. The parameters analyzed were the weight of dry leaf biomass (DLB), and the weight of dry root biomass (DRB). The length of the roots was measured with a ruler graduated in millimeters. The DLB and DRB were obtained by separating the leaf and root compartments, with subsequent drying of the materials in a forced ventilation oven at $45^{\circ} \mathrm{C}$, until they reached a constant weight.
The increment of fresh biomass, root length and number of sprouts over time was analyzed using ANOVA of the repeated measurements. The data of the dry biomass at the end of the experiment were submitted to analysis of variance (ANOVA) and the means compared by the Tukey test at a $5 \%$ probability level. The statistical analyses were performed using the statistical package Systat version 12.0.

\section{Results}

The water $\mathrm{pH}$ varied between 3.9 and 6.3 , and conductivity varied between 47.1 and $73.9 \mu \mathrm{S} / \mathrm{cm}$. No plant mortality was observed in any of the three treatments. However, in T1 (well water) growth was inhibited early in the experiment (Fig. 1A). In T2 (Catalão Lake water) significant biomass accumulation was expected due to the use of the same water from the plant collection site, however, from the $20^{\text {th }}$ day onwards, there was a reduction in the gain of fresh biomass (Fig. 1A); the leaves in T2 were losing their color and, at the end of the experiment, they presented generalized chlorosis both in the old fronds and in the sprouts (see Tabs. S1, S2 and Fig. S1 in supplementary material). An intense growth of algae was also observed in this treatment. In T3 (well water + mineral supplement), fresh biomass has increased considerably throughout the treatment (Fig. 1A). Thus, total fresh biomass was influenced by treatments $(\mathrm{F}=179.657, \mathrm{p}<0.0001)$, time $(\mathrm{F}=156.709$, $\mathrm{p}<0.0001)$ and interaction between time and treatment $(\mathrm{F}=82.296, \mathrm{p}<0.0001)$ (Fig. 1A).

Root length was also influenced by treatments $(\mathrm{F}=78.539$, $\mathrm{p}<0.0001)$, time $(\mathrm{F}=80,319, \mathrm{p}<0.0001)$, and interaction time and treatment $(\mathrm{F}=23.725, \mathrm{p}<0.0001)$. Only the T3 plants showed root growth (Fig. 1B) and the production of new roots. The number of sprouts was influenced by treatments $(\mathrm{F}=70.247, \mathrm{p}<0.0001)$, time $(\mathrm{F}=62.898, \mathrm{p}<0.0001)$ and interaction time and treatment $(\mathrm{F}=29.641, \mathrm{p}<0.0001)$. Treatment 3 showed the greatest increase in the number of sprouts. In treatments 1 and 2, the plants formed sprouts, but the increment was not significant (Fig. 1C).

In treatment 3 there was a greater increase in dry leaf biomass than $\mathrm{T} 1$ and $\mathrm{T} 2(\mathrm{~F}=83.467, \mathrm{p}<0.0001$; Fig. 2); greater dry root biomass $(\mathrm{F}=30.468, \mathrm{p}<0000.1 ; \mathrm{Fig} .2)$ and total dry biomass ( $\mathrm{F}=78.028, \mathrm{p}<0000$; Fig. 2$)$.

\section{Discussion}

Although no plant mortality was observed in all three treatments, this study revealed that the cultivation of the species $C$. pteridoides as a crop in the artesian well water with a nutritive solution to be the most promising cultivation practice. The water of the artesian well alone (T1 treatment) may not have provided the necessary amount of nutrients, since $C$. pteridoides prefers nutrient-rich environments 
(Piedade et al. 2019). On the other hand, we expected a higher growth and biomass accumulation in $\mathrm{T} 2$ in which the water of the natural environment was used, due to the high amount of nutrients dissolved in the water (Furch 1997). This may be explained by the process of decantation that occurs after some time, which favors the penetration of light, leading to the development of algae (König 2000), as observed in this study.

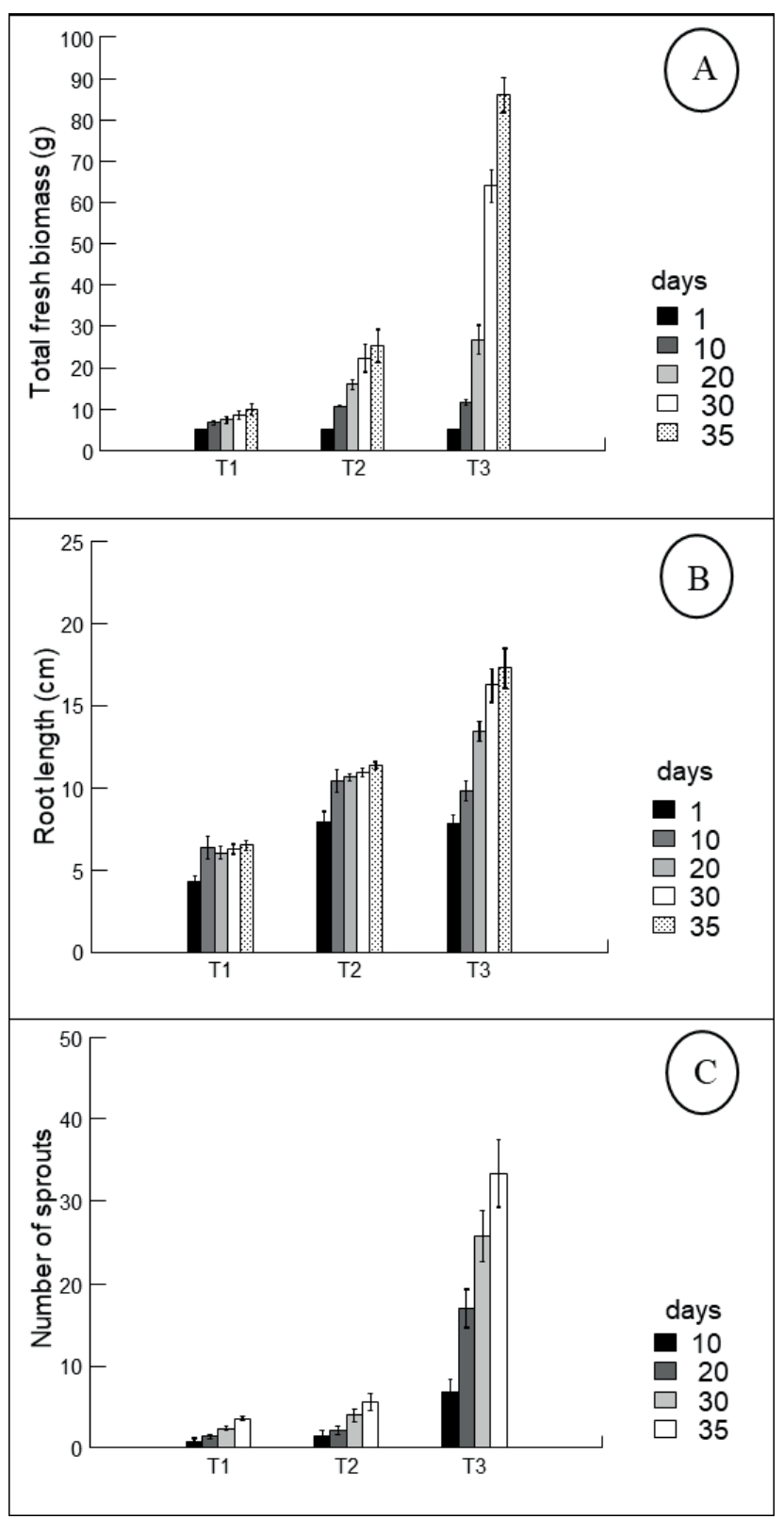

Figure 1. Effect of nutrient level on C. pteridoides: A) Total fresh biomass (g); B) Root length (cm); C) Number of sprouts. Where: T1 = Water from the Instituto Nacional de Pesquisas da Amazônia (INPA) artesian well (control); T2 = Water from the Catalão Lake; T3 $=$ Water from the INPA artesian well + nutritive solution. Error bars denote the standard deviation. Different letters indicate significant differences according to Tukey test $(\mathrm{p}<0.05)$.
Free-floating plants affect phytoplankton biomass through competition for solar radiation, nutrients and secretion of allelopathically active compounds (Dent et al. 2002; Van Donk \& Van de Bund 2002; Gross 2003; Dong et al. 2018). In a field mesocosm experiment in a temperate lake, there was decrease in phytoplankton biomass in the presence of aquatic macrophytes (O'Farrell et al. 2009). In warm, nutrient-rich wetlands, dominant floating plant stands also
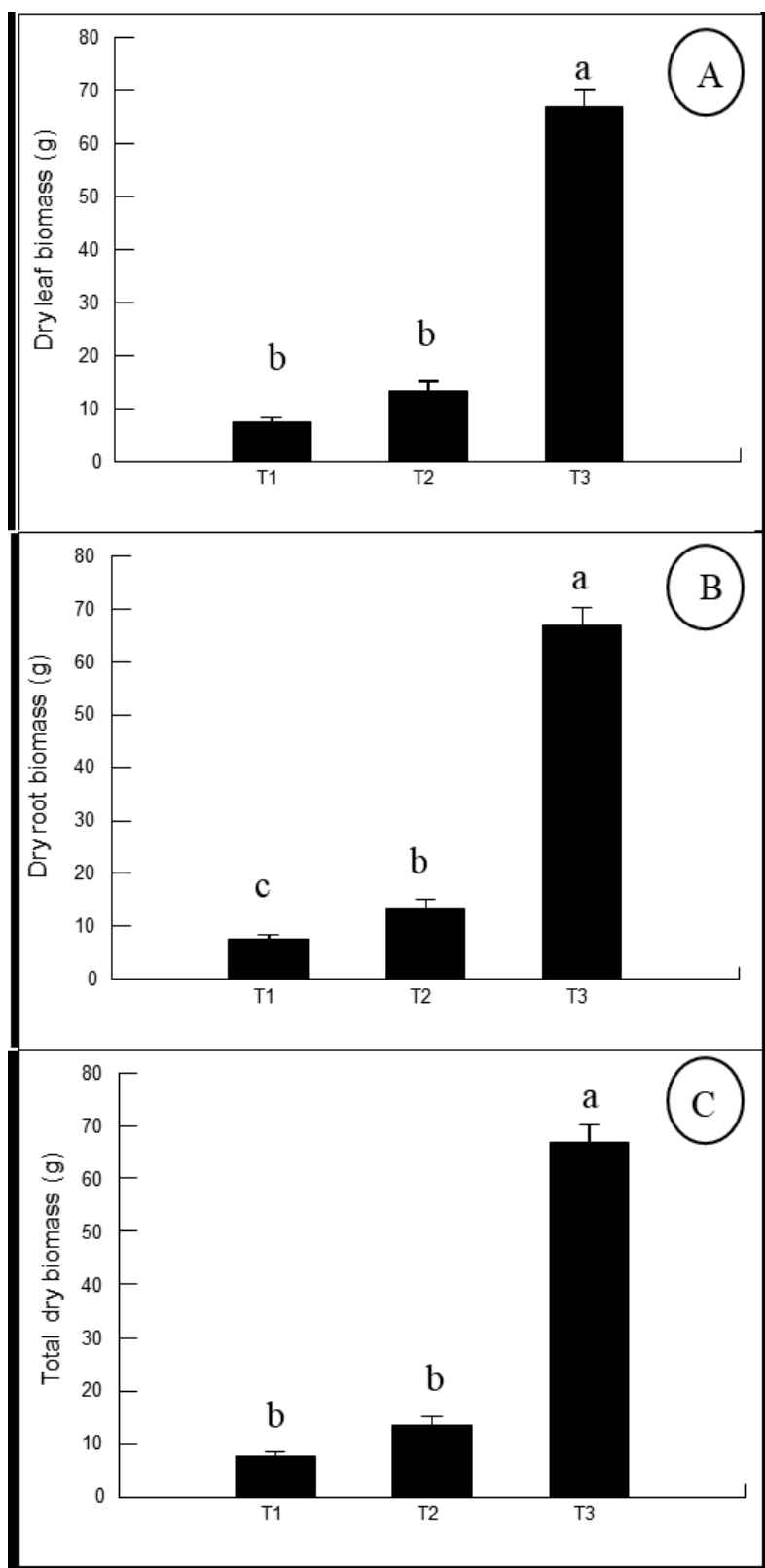

Figure 2. Effect of nutrient level on dry biomass of frond and root of C. pteridoides. Where: T1 = Water from the Instituto Nacional de Pesquisas da Amazônia (INPA) artesian well (control); T2 = Water from the Catalão Lake; T3 = Water from the INPA artesian well + nutritive solution. Error bars denote the standard deviation. Different letters indicate significant differences according to Tukey test $(\mathrm{p}<0.05)$. 
result in low phytoplankton biomass (Bicudo et al. 2007; Tezanos Pinto et al. 2007). However, information about competition between algae and floating plants is scarce, and the observed patterns are not consistent (Meerhoff et al. 2003). Thus, on its own, the growth of algae in the T2 treatment may not explain the unexpected low performance in growth in comparison to the T3 treatment, especially since the water of the tray was changed weekly using fresh water from the Catalão Lake. Therefore, studies regarding algal competition and floating aquatic macrophytes need to be performed in order to understand the real influence of algae on hydroponic production systems.

The fresh and dry total biomass obtained in T3 allowed us to infer that the nutrient solution promoted better development of the root system and the aerial part of C. pteridoides, which shows that the nutrient concentration of the mineral nutrient solution selected is adequate for the cultivation of this species. The correct dosage of the nutrient solution is fundamental for the development, the increase in productivity, and the quality of the vegetable to be produced. Several hydroponic crops have been shown to be unsuccessful when provided with incorrect nutritional management (Furlani et al. 2009). In T3, the $\mathrm{pH}$ of the water varied between 3.9 and 6.3, an important indicative of the adequacy of the solution. The nitric and ammoniacal forms in the composition of the nutrient solution provide greater pH stability (Andriolo 1999). Values below 4.0 affect the integrity and permeability of cell membranes, which can lead to loss of nutrients already absorbed by the plant and delayed root growth; values greater than 6.5 can lead to the precipitation of elements such as calcium, phosphorus, iron and manganese, making them unavailable to plants (Martinez 2002).

When compared to other aquatic macrophyte species, the total biomass production of $C$. pteridoides over 35 days at T3 treatment can be considered remarkably high, since it increased by $1,720.0 \%$. Eichhornia crassipes increased $177.6 \%$ and Egeria densa Planch. $2 \%$ in their production of fresh biomass in 40 days when cultivated with organic aquaculture effluents (Henry-Silva et al. 2008). In comparison to other vegetables that are hydroponically cultivated, C. pteridoides also performed very well. For example, arugula (Eruca sativa) increased its fresh aerial biomass by $29.0 \%$ in 30 days (Genuncio et al. 2011), while unconventional food plants (UFPs), such as Florida spinach (Talinum triangulare), which was grown using hydroponics, increased its fresh aerial biomass by $27.0 \%$ in 21 days (Araújo et al. 2018).

Considering the biomass production, the mineral content (Tab. S1 in supplementary material) and the protein content (11.3\%) (Albuquerque 1981) of C. pteridoides, the species has proved to be a very promising vegetable for human consumption using a low-cost mineral nutrition kit. In fact, the congeneric species, Ceratopteris thalictroides, is regularly consumed raw or cooked in several Asian countries (Edwards 1980), or even cultivated as a spring vegetable in
Japan (Cook et al. 1974). The practice of cultivating floating crops (Radulovich et al. 2015) is scarce, if not absent, in the floodplains of the Brazilian Amazon, since the flood-pulse impedes plantations during the period of high water levels (Junk et al. 2000). The introduction of such a practice using C. pteridoides may enhance the economy and food security especially of the Amazonian riverine populations.

\section{Conclusion}

This study has confirmed that $C$. pteridoides has great potential for cultivation. The nutritive solution caused a high accumulation of biomass and, thus, it can be cultivated all year round. Since the species is particularly rich in $\mathrm{K}, \mathrm{Ca}, \mathrm{Fe}$, and $\mathrm{Zn}$, which are essential dietary minerals, we may conclude that its ingestion could contribute to a large proportion of the body's mineral requirement if consumed on a regular basis. We also suggest palatability tests to promote consumption by the local population. Further experiments in the field, where water current and a continuous natural nutrient supply may allow a better growth than that achieved in our greenhouse experiments, are also recommended.

\section{Acknowledgements}

We thank the Brazilian Council for Scientific Research (CNPq) for financing the research project, the Long-term Ecological Research Network-PELD (CNPq/CAPES/ FAPS/BC, NEWTON FUND PROGRAM; Grant Number: 441590/2016-0 and MCTI/CNPq/FAPs; Grant Number: 403792/2012-6); Coordenação de Aperfeiçoamento de Pessoal de Nivel Superior - Brasil (CAPES) - Finance Code 001; We received further support from the INCTADAPTA (CNPq Grant Number: 465540/2014-7; FAPEAM Grant Number: 062.1187/2017). We also would like to thank MAUA group INPA-PPI PPI: 1090-5 for support and logistics.

\section{References}

Abou-Hadid AF, Abd-Elmoniem EM, El-Shinawy MZ, Abou-Elsoud M. 1995. Electrical conductivity effect on growth and mineral composition of lettuce plants in hydroponic system. Strategies for Market Oriented Greenhouse Production 434: 59-66.

Albuquerque BW. 1981. Plantas forrageiras da Amazônia. I-Aquáticas flutuantes livres. Acta Amazonica 11: 457- 471.

Andriolo JL. 1999. Fisiologia das culturas protegidas. Santa Maria, UFSM. Araújo FS, Silva Filho DFD, Souza LAGD. 2018. Cultivo do cariru (Talinum triangulare (Jack. Willd.), em sistema de produção hidropônico flutuante. Scientia Plena 14: 7. doi: 10.14808/sci.plena.2018.070201

Bicudo DD, Fonseca BM, Bini LM, Crossetti LO, Bicudo CE, Araújo-Jesus TA. 2007. Undesirable side-effects of water hyacinth control in a shallow tropical reservoir. Freshwater Biology 52: 1120-33.

Brasil. 2010. Ministério da Agricultura, Pecuária e Abastecimento. Manual de hortaliças não-convencionais. Ministério da Agricultura, Pecuária e Abastecimento. Secretaria de Desenvolvimento Agropecuário e 


\section{Biomass production of the aquatic macrophyte Ceratopteris pteridoides (Hook.) Hieron (Pteridaceae) in nutrient addition treatments}

Cooperativismo. Brasília: Mapa/ACS. http://www.abcsem.com.br/ docs/manual_hortalicas_web.pdf.

Brito JG, Alves LF, Espirito-Santo HMV. 2014. Seasonal and spatial variations in limnological conditions of a floodplain lake (Lake Catalão) connected to both the Solimões and Negro Rivers, Central Amazonia. Acta Amazonica 44: $121-133$.

Chambers PA, Lacoul P, Murphy KJ, Thomaz SM. 2007. Global diversity of aquatic macrophytes in freshwater. In: Balian EV, Lévêque $C$, Segers H, Martens K (eds.) Freshwater Animal Diversity Assessment. Developments in Hydrobiology. Dordrecht, Springer. p. 9-26.

Cook CDK, Gut BJ, Rix EM, Sclneller J. 1974. Water Plants of the World: a manual for the identification of the genera of freshwatcr macrophytes. Netherlands, Springer Science \& Business Media.

Dent CL, Cumming GS, Carpenter SR. 2002. Multiple states in river and lake ecosystems. Philosophical Transactions of the Royal Society of London. Series B: Biological Sciences 357: 635- 645.

Dias JCS. 2015. Plant breeding for harmony between modern agriculture production and the environment. Agricultural Sciences 6: 87-116.

Dias JS. 2012. Nutritional quality and health benefits of vegetables: A review. Food and Nutrition Sciences 3: 1354-1374.

Dong J, Gao Y, Chang M, et al. 2018. Colony formation by the green alga Chlorella vulgaris in response to the competitor Ceratophyllum demersum. Hydrobiologia 805: 177- 187.

Edwards P. 1980. Food potential of aquatic macrophytes. ICLARM Studies and Reviews 5. International Center for Living Aquatic Resources Management, Manila, Philippines. https://digitalarchive. worldfishcenter.org/handle/20.500.12348/3646. 18 Aug. 2020

Furch K. 1997. Chemistry of várzea and igapó soils and nutrient inventory of their floodplain forests. In: Junk WJ. (ed.), The Central Amazon Floodplain Berlin, Heidelberg, Springer. p. 47-67.

Furlani PR, Silveira LCP, Bolonhezi D, Faquin V. 2009. Cultivo Hidropônico de Plantas: Parte 2 - Solução Nutritiva. Campinas, Instituto Agronômico.

Genuncio GDC, Silva RAC, Sá NM, Mary W, Zonta E. 2011. Produtividade de rúcula hidropônica cultivada em diferentes épocas e vazões de solução nutritiva. Horticultura Brasileira 29: 605- 608.

Gross EM. 2003. Allelopathy of aquatic autotrophs. Critical Reviews in Plant Sciences 22: 313-339.

Guterres MG, Marmontel M, Ayub DM, Singer RF, Singer RB. 2008. Anatomia e morfologia de plantas aquáticas da Amazônia: utilizadas como potencial alimento por peixe-boi amazônico. Belém, Instituto de Desenvolvimento Sustentável Mamirauá.

Henry-Silva GG, Camargo AF, Pezzato MM. 2008. Growth of free-floating aquatic macrophytes in different concentrations of nutrients. Hydrobiologia 610: 153-160.

Hirai RY, Prado J. 2020. Ceratopteris in Flora do Brasil 2020 em construção. Jardim Botânico do Rio de Janeiro. http://reflora.jbrj.gov.br/reflora/ floradobrasil/FB91878. 09 Mar. 2020.

Johns T, Eyzaguirre PB. 2006. Linking biodiversity, diet and health in policy and practice. Proceedings of the Nutrition Society 65: 182-189.

Junk WJ, Ohly JJ, Piedade MTF, Soares MGM. 2000. The Central Amazon FloodplaIn Actual Use and Options for a Sustainable Management. Leiden, Backhuys Publishers.

Kays SJ, Dias JCS. 1995. Common names of commercially cultivated vegetables of the world in 15 languages. Economic Botany 49: 115-152.

Kinupp VF, Barros IBI. 2008. Teores de proteína e minerais de espécies nativas, potenciais hortaliças e frutas. Ciências e Tecnologia de Alimentos 28: 846-857.

Kinupp VF, Lorenzi H. 2014. Plantas alimentícias não convencionais (PANC) no Brasil: guia de identificação, aspectos nutricionais e receitas ilustradas. 1st. edn. Nova Odessa, Plantarum.

König A. 2000. Biología de las lagunas de estabilización: algas. In: Mendonça SR. (ed.) Sistemas de Lagunas de Estabilization: cómo utilizar aguas residuales tratadas en sistemas de regadío. Bogotá, McGraw Hill Interamericana, S.A. p. 44- 67.

Liu Y, Wujisguleng W, Long C. 2012. Food uses of ferns in China: a review. Acta Societatis Botanicorum Poloniae 81: 263-270.

Mafeo TP, Mashela PW. 2009. Responses of germination in tomato, watermelon and butternut squash to Cucumis bionematicide. Journal of Agriculture and Environment Science 6: 215-219.

Martinez HEP. 2002. O uso do cultivo hidropônico de plantas em pesquisa. Viçosa, Editora UFV.

Meerhoff M, Mazzeo N, Moss B, Rodríguez-Gallego L. 2003. The structuring role of free-floating versus submerged plants in a subtropical shallow lake. Aquatic Ecology 37: 377-91.

O’Farrell Inés, Tezanos Pinto P, Rodriguez PL, Chaparro G, Pizarro HN 2009. Experimental evidence of the dynamic effect of free-floating plants on phytoplankton ecology. Freshwater biology 54: 363-375.

ONU - United Nations Organization. 2015. Probabilistic populations projections based on the world population prospects: Revision. Population Division, DESA.ONU. http://esa.un.org/unpd/ppp/. 24 Jul. 2020.

Packer LA. 2012. Biodiversidade como bem comum: direitos dos agricultores, agricultoras, povos e comunidades tradicionais. Curitiba, Terra de Direitos.

Panda S. 2015. A study on leaves and fronds consumed as vegetables and salads in West Bengal state, India. International Journal of advances in Pharmacy. Biology and Chemistry 4: 685-697.

Piedade MTF, Junk WJ, D’angelo SA, et al. 2010. Aquatic herbaceous plants of the Amazon floodplains: state of the art and research needed. Acta Limnologica Brasiliensia 22: 165-178.

Piedade MTF, Junk WJ, Long SP. 1991. The productivity of the C4 grass Echinochloa polystachya on the Amazon floodplain. Ecology 72: 1456-1463.

Piedade MTF, Junk WJ. 2000. Natural grassland and herbaceous plants in the Amazon floodplain and their use. In: Junk WJ, Ohly JJ, Piedade MTF, Soares MGM. (edn.) The central Amazon floodplain: actual use and options for a sustainable management. Leiden, Backhuys Publishers. p. 269-290.

Piedade MTF, Lopes A, Demarchi LO, et al. 2019. Guia de campo de herbáceas aquáticas: várzea Amazônica. 1st. edn. Manaus, Instituto Nacional de Pesquisas da Amazônia - Inpa.

Radulovich R, Umanzor S, Mata R, Elizondo D. 2015. Aquatic agriculture: floating crops on lakes. World Aquaculture 46: 62- 67.

Rodrigues LRF. 2002. Cultivo pela técnica de hidroponia. Técnicas de cultivo hidropônico e de controle ambiental no manejo de pragas, doenças e nutrição vegetal em ambiente protegido. Jaboticabal, Fundação de Apoio a Pesquisa, Ensino e Extensão - Funep.

Sioli H. 1968. Hydrochemistry and geology in the Brazilian Amazon region. Amazoniana 1: 267-277.

Souto LFL, Oliveira TCDS, Silva MDSRD. 2015. Spatial variation of cations, anions and physicochemical variables in the Solimões-Amazonas River, between Manaus and Jutaí, Amazon Basin. Acta Amazonica 45: 415-424.

Souza-Bastos LR, Val AL, Wood CM. 2017. Are Amazonian fish more sensitive to ammonia? Toxicity of ammonia to eleven native species. Hydrobiologia 789: 143-155.

Tezanos Pinto P, Allende L, O'Farrell I. 2007. Influence of free-floating plants on the structure of a natural phytoplankton assemblage: an experimental approach. Journal of Plankton Research 29: 47-56.

Thomaz SM, Esteves FA, Murphy KJ, Dos Santos AM, Caliman A, Guariento RD. 2009. Aquatic macrophytes in the tropics: ecology of populations and communities, impacts of invasions and human use. Tropical Biology and Conservation Management 4: 27-60.

Van Donk E, Van de Bund WJ. 2002. Impact of submerged macrophytes including charophytes on phyto- and zooplankton communities: allelopathy versus other mechanisms. Aquatic Botany 72: 261-274. 